\title{
Emerging viral infectious disease threat: Why Tanzania is not in a safe zone
}

\author{
CHACHA D. MANGU*, CHRISTINA K. MANYAMA, LWITIHO SUDI, ISSA SABI, HENRY MSILA, NYANDA E. \\ NTINGINYA, GODLOVE CHAULA and LEONARD MABOKO \\ National Institute for Medical Research, Mbeya Research Centre, Mbeya Tanzania
}

\begin{abstract}
Emerging diseases are global threat towards human existence. Every country is exposed to potentially emergence of infectious diseases. Several factor such as changes in ecology, climate and human demographics play different roles in a complex mechanism contributing to the occurrence of infectious diseases. Important aspects towards control in case of outbreaks are surveillance, preparedness and early response. Tanzania should therefore take opportunity of the calm situation currently present, to prepare. Except for HIV/AIDS, Tanzania has not experienced a major public health threat. However, the question is, is the country safe from emerging and re-emerging infectious diseases? In this article we try to explore the danger of emerging infectious disease (EID) epidemics in Tanzania and the risks attached if an outbreak is to occur. The aim is to formulate recommendations to the government, responsible authorities and general population of what can be done to improve the level of EID preparedness in the country. In conclusion, it is important to strengthen the capacity of community and healthcare staffs on how to respond to potential infectious disease outbreaks. Community-based surveillance systems should be incorporated into the national systems for early detection of public health events. It is also critical to enhance one health approach to increase cross-sectoral information sharing, surveillance and interventional strategies as regards to preparedness and response to disease outbreaks.
\end{abstract}

Keywords: emerging, virus diseases, threat, epidemics, preparedness, Tanzania

\section{Background}

Throughout history of mankind, infectious diseases have been emerging. New pathogens have been identified while those previously identified remain to cause threat to human health and existence (Morse, 1995). There are two categories of emerging infectious diseases (EID) -the newly emerging and re-emerging. By definition, emerging disease are those disease that newly appear in human population for the first time caused by either new pathogens or variant of previously known pathogens; whereas re-emerging disease are those previously existed but occurring in increasing incidences and/or wide geographical distribution or in drug resistant form or reappear after apparent control or elimination (Morse, 1995; Morens \& Fauci, 2013). For the purpose of this article, the term emerging diseases will refer to both emerging and re-emerging infectious diseases.

Infectious pathogens that have emerged recently are well known for their ability to cause diseases (highly virulent) and death (fatal) in human population thereby posing a considerable threat to public health. Although research has played its role in trying to explain emerging diseases, but the actual drivers of these infections are yet to be elucidated. Until now, it has been appreciated by numerous investigators that emerging diseases are a result of complex mechanisms (Wilcox \& Colwell, 2005). The mechanisms involve an infectious agent and its pathogenesis, vectors, natural hosts, as well as environmental, climatic and ecological systems alterations as a result of changes in human demographics. Eventually, a combination of factors provides emerging viral agents with a favourable new ecological niche (Racaniello, 2004; Wilcox \& Colwell, 2005). Significant knowledge gap therefore still exist even for the most studied EID consequently renders prediction of where and when such diseases would occur almost impossible.

\footnotetext{
${ }^{*}$ Correspondence: E-mail address: cmangu@nimr-mmrc.org
} 
The sting of emerging infectious diseases is ever present with us. In recent years, the world has been experiencing, in varying degrees, epidemics that are caused by either new or recurrent infectious pathogens which together threaten human existence. From HIV pandemic which emerged in early 1980 s with death toll reaching to about 39 million through influenza epidemics, Severe Acute Respiratory Syndrome (ARS) and to a recent Ebola virus epidemic in West Africa claiming nearly 9,000 lives only in about a year after it started, serves as a strong reminder of our ongoing vulnerability to viral pathogens (Marston et al., 2014; WHO, 2014). Table 1 below shows some of the important recently emerged viral diseases. Some of EID currently reported to occur in different parts of the world causing both severe illnesses and death in humans are Avian Influenza $\mathrm{H} 7 \mathrm{N9}$ in Guangdong, China; Avian Influenza $\mathrm{H}_{5} \mathrm{~N}_{1}$ in Egypt; Avian Influenza $\mathrm{H}_{3} \mathrm{~N}_{2}$ in Tawain; Middle East Respiratory Syndrome Coronavirus (MERS Co-V) in Saudi Arabia; Ebola in West Africa; Hantavirus in Panama; Nipah Encephalitis in Bangladesh; and Crimean-Congo Haemorrhagic Fever in India (ProMED, 2015) (Table 1).

Except for HIV/AIDS, Tanzania has not experienced a major threat directly and in its full intensity, but the question is, are we safe from these diseases? In this article we trying to explore the danger of EID epidemics in Tanzania just like any other country and the risks attached if an outbreak is to occur. We aim to formulate recommendations to the government, responsible authorities and general population of what can be done to improve the level of EID preparedness in the country.

Table 1. Emerged infectious viral pathogens and diseases they cause in humans, 1973-2009

\begin{tabular}{|c|c|c|c|}
\hline Pathogen & Disease it causes & $\begin{array}{l}\text { Year } \\
\text { Emerged }\end{array}$ & Affected countries \\
\hline Rotavirus & Childhood gastroenteritis & 1973 & Global infections \\
\hline Ebola Virus & Ebola virus disease & 1976 & $\begin{array}{l}\text { Democratic Republic } \\
\text { of Congo Guinea, Mali, } \\
\text { Sierra Leone, Uganda, } \\
\text { Sudan, USA, Spain, } \\
\text { UK, Italy }\end{array}$ \\
\hline HIV & AIDS & 1983 & Global Epidemic \\
\hline Hepatitis C Virus & Hepatitis & 1989 & Global Epidemic \\
\hline $\begin{array}{l}\text { Sin Nombre Virus } \\
\text { (Hantavirus) }\end{array}$ & $\begin{array}{l}\text { Hantavirus Pulmonary } \\
\text { Syndrome }\end{array}$ & 1993 & $\begin{array}{l}\text { Korea, } \\
\text { Kazakhstan, German, } \\
\text { Argentina }\end{array}$ \\
\hline Human Herpesvirus 8 & Kaposi Sarcoma & 1995 & Global Infection \\
\hline Influenza Virus A $\mathrm{H}_{5} \mathrm{~N}_{1}$ & Influenza & 1997 & $\begin{array}{l}\text { China, USA, France, } \\
\text { United Arab Emirates }\end{array}$ \\
\hline Marburg Virus & Marburg Virus Disease & 1998 & Uganda \\
\hline SARS Coronavirus & $\begin{array}{l}\text { Severe Acute Respiratory } \\
\text { Syndrome }\end{array}$ & 2003 & $\begin{array}{l}\text { Saudi Arabia, Korea, } \\
\text { China, USA, UK, }\end{array}$ \\
\hline MERS Coronavirus & $\begin{array}{l}\text { Middle East Respiratory } \\
\text { Syndrome }\end{array}$ & 2006 & $\begin{array}{l}\text { Saudi Arabia, Korea, } \\
\text { China }\end{array}$ \\
\hline LuJo virus & LuJo Haemorrhagic fever & 2008 & Zambia, South Africa \\
\hline Avian Influenza $\mathrm{H}_{1} \mathrm{~N} 1$ & Swine Flue & 2009 & Global infections \\
\hline
\end{tabular}

Source: NIH, Biological Sciences Curriculum Study (science.education.nih.gov/supplements), Morse 1995, Morens, 2004, 2008, 2013; Briese et al., 2009) 


\section{Presence of emerging diseases threat in Tanzania cannot be ruled out}

Although there are not that many epidemics or outbreaks of emerging diseases in Tanzania, their presence cannot be ruled out. A review on EID that covered in the past five decades in Tanzania identified evidences for five viral infectious diseases in humans namely Rift Valley fever, Influenza H1N1, Rubella, HIV1 and Dengue and Chikungunya (Karimuribo et al. 2011; Vairo et al., 2016; Chipwaza et al., 2014; Kajeguka et al., 2016). As stated earlier on, there is very low suspicion index and most of our health care workers including clinicians are not trained to diagnose and report emerging diseases of particular importance. The fact that these diseases are not reported frequently does not rule out their presence in among the communities in the country. Seroprevalence surveys conducted in different areas of the country have confirmed exposure to several potentially life threatening EID viruses such as Rift Valley fever, Chinkungunya, yellow fever, dengue, hepatitis and influenza (Heinrich et al. 2012; Weller et al. 2014, Vairo et al., 2012; 2016; Chipwaza et al., 2014; Kajeguka et al., 2016). Epidemiologically, major outbreaks are preceded by research results which indicate the presence of immunological markers therefore confirming exposure to infectious pathogens and transmission. Dengue fever outbreak of 2014 in Dar-es-salaam is a good example (Mboera et al. 2015; Vairo et al., 2016). Such research findings that show exposure of the population to emerging infectious agents should serve as early warnings for possible future outbreaks hence a call for preparedness at all levels.

\section{Factors that can potentially contribute to emergence of infectious diseases in Tanzania}

\section{Environmental and ecological changes}

Major ecological changes experienced today are due to alteration of natural ecosystem as a result of land use transformation either for agricultural intensification and livestock grazing purposes or rural urbanization (FAO, 2013). There is an ever increasing proximity between human population and wildlife leading to enhanced contacts with pathogen-carrying natural hosts such as wild mice, primates, bats just to mention a few. Man-made environmental and ecological changes firstly, expose human population to increased contact with natural host or reservoirs of viral pathogens. This is through increasing proximity as a result of changes in natural habitat of natural hosts of infectious pathogens by moving closer to human population and human encroachment in natural habitat of natural hosts (Morse 1995; Wilcox \& Colwell 2005). Additionally, by altering conditions to favour the increase of pathogens within their natural hosts, reservoir or vectors. Moreover, the increasing contact of human and wildlife favours "microbial transfer" from natural hosts to humans in which they are capable of causing diseases (Morse, 1991). This factor has been especially important in causing new diseases in human population of zoonotic in nature.

Secondly, ecological changes may force natural hosts of pathogens to migrate into a different geographical location hence microbial transfer to a new geographical area in which they previously not existed. This will cause emergence of diseases in a completely new location. This phenomenon of microbial transfer, both from natural host to humans and from one geographical location into a new one is known as microbial traffic (Morse, 1991).

Furthermore, climatic changes as part of environmental changes marked by increasing temperatures, varying seasons of high and low rainfalls, floods and humidity expose the population to increased risks of emerging diseases. This is achieved through changes in biological and ecological processes that may influence the disease transmission and food yield (Wilcox \& Colwell, 2005). For instance, seasons of high rains may result into floods which forms standing water paddles that become mosquito breeding sites that can transmit viral diseases, such as Rift Valley fever. In years 
with little rains, lack of enough food forces people to eat bush meat and fruits from which they can contact pathogens (FAO, 2013).

\section{Urbanization and human demographic changes}

Growth of cities and rural urbanization as a result of increase in population density is one of the sources of ecosystem and natural habitat alteration which may be a source of exposure to infectious agents (Morse, 1995). Continuous migration into major cities for business or jobs and fortune search increases crowded and overpopulated settlements. Overwhelmed health, sanitation, waste infrastructure systems due to increased waste production leads to waste and litter piles in most of city areas. This, therefore increases the chances of pathogens and rodents to multiply and persist in human population. A recent (2014) epidemic of dengue in Dar-es-Salaam, Tanzania is an example of how the mosquito vector, Aedes aegypti, takes advantage of improper disposal of, increase piles of poorly disposed old tires and plastic containers in city to multiply and spread dengue virus in human population (Mboera et al., 2016). In Tanzania, population growth has been documented to increase from $5.7 \%$ in 1967 to $29.1 \%$ in 2012 with an increase of $6.6 \%$ within 10 years from 2002 to 2012 (URT, 2013) a total population increase of 31.6 million of which 12.0 million were absorbed into urban areas. Rural population has also increased to 19.6 million estimated to be nearly threefold increase over 1967. Such demographic changes increase pressure and changes in land use and greatly alter the ecosystems while putting pressure on hygiene and waste disposal in most of the major cities (Muzzini, 2008; Wenban-Smith, 2014). Sewage spill over into clean water systems especially in rain seasons may be the cause of major outbreaks of faecal-oral virus diseases such as hepatitis (Greer, 2014). A newly introduced pathogen in an overcrowded city, quickly spread as opposed to a scarcely populated rural area. However, human encroachments in natural habitat of pathogens' vectors and host in rural urbanization, complemented by rural emigration into cities and improving transportation system will possibly play a role of spreading pathogen(s) that arise in isolated rural areas to a larger population. Without this enhancement pathogen(s) may have otherwise remained restricted and localized (Morse, 1995).

\section{Blooming international travel and trade}

Globalization and international trade as well as international migrations have recently increased international travels by every means known. Increase in human travel is a result of various factors and populations. Immigrants, refugees, missionaries, workers, hajj and traders all contributes to a general picture of global travel in which process they carry with them microbes, risk behaviours and activities (Wilson, 1995). However, with more effective means of transports, worldwide human contact has been significantly multiplied and this can be the source of fast spread of a pathogen from epidemic areas to cause a global epidemic (Fidler, 1996). International travel has been one of major means of spread of emerging pathogens throughout history. However, the opportunities have increased exponentially in recent years due to global trade fuelled by ever advancing air transportation (Tatem, 2006). Tanzania with two international airports and receiving over 2 million international passengers annually (ICAO, 2013; Suleiman 2014) is connected to a complex interconnections involving more billions of passenger-kilometres performed globally. These numbers are expected to continue increasing yearly. Despite airport precautions and controls of infectious disease, the country is still openly exposed to any pathogen that might be causing epidemics from all around the world. International business with countries experiencing disease outbreaks therefore can be one of the reasons why Tanzania is not in a safe zone as far as viral emerging diseases threat is concerned. 


\section{Increased demand of animal protein}

There is a global increase need of animal protein as a source of energy and nutrients (FAO, 2013). As a result, increased human activities in handling animals, poultry and their products to meet the demand, expose human population to EIDs that are zoonotic in nature. Most of these contacts in many regions of the developing world including Tanzania occur without any personal protective equipment (PPE). There are evidences that practices of keeping different pigs, poultry and other animals or birds in close contact can create a "culture media" for new strains of pathogens which may be a source of an epidemic with completely new presentations; an avian influenza outbreak in China for instance is suspected to be due to keeping swine, poultry and waterfowls in close proximity (Trifonov et al., 2009). Major outbreaks including those which occurred during the $19^{\text {th }}$ and $20^{\text {th }}$ centuries have been zoonotic in nature associated with close contacts between human population and animals (Peters, 1999; Gibbs, 2005; Kilbourne, 2006; FAO, 2013). There is an increasing practice in Tanzania to have some families especially those with middle and low income to keep cattle, pigs and poultry at the back yards of their houses and in close proximity both in rural and urban settings (MALF, 2016).

\section{Genetic mutation and adaptations}

With an example of the avian influenza, viruses have shown considerable large capacity of developing mutation which results into new pathogenic strains. Arising of new viral strain is due to periodic genetic re-assortment between two or more different viral strain from two or more different hosts to produce an "antigenic shift". Antigenic shift is the process by which two or more different strains of a virus, or strains of two or more different viruses, combine to form a new subtype having a mixture of the surface antigens of the two or more original strains. Antigenic shifts are the major causes of new diseases with completely new presentations leading to deadly pandemics (Morse, 1991; Monath, 1993). Moreover, after several years, shifted viruses may undergo continual genetic changes called "genetic drifts". Genetic (allelic) drift is the change in the frequency of a gene variant (allele) in a population due to random sampling. Genetic drifts allow viral strains to escape immunity previously raised as a result of infection from genetically different influenza virus (Morens et al., 2004; Trifonov et al., 2009). This exposes an individual previously infected by a similar virus to a second episode of a potentially fatal illness that is caused by a slightly different strain of the same virus. Although seroprevalence surveys have shown that Tanzania population has been exposed to pathogens that can potentially cause epidemic, there is a herd immunity that keeps this population from outbreaks. However, this phenomenon still poses danger of epidemics to arise for a new strain of previously existed virus.

\section{Deficiencies in public health infrastructure and surveillance}

Established, well planned and working public health infrastructures minimize the possibility of major outbreaks and works to minimize spread of such outbreaks if at all they occur. Unfortunately, the public health system in Tanzania as in most of developing countries has several major breaches including inadequate surveillance and hierarchical reporting systems for emerging infectious diseases as well as weak response capabilities in case of outbreak. An assessment conducted in 2012 showed major infrastructure and surveillance deficiencies (Scholz et al., 2015). Although there are centres that are capable of handling patients in critical conditions for care provision necessary in highly virulent pathogens but health care facilities that are specialized and designated to provide high-level isolation and quarantine in case of highly contagious pathogens in Tanzania are deficient. Weak outbreak response and containment can facilitate the spread of infection in health care settings. In most of developing countries, weaknesses have been documented in laboratory capacities, health information systems, communication and human resource who are not trained to 
identify and handle infectious patients in biosafety practices optimized to prevent spread of potentially transmissible pathogens as well as unmotivated human resources (Thompson \& Zwi, 2011). In such cases, healthcare workers fall into a danger to acquire infection in very early stages of an outbreak; this will further paralyze the ability of the health system to respond to outbreaks.

\section{Why is Tanzania at risk of Emerging Infectious Diseases?}

\section{Presence of natural hosts of potentially fatal EIDs}

The fact that we share habitat with natural hosts of potentially deadly EID pathogens such as bats, monkeys and other primates as well as mouse, we may then not always be safe. We would like to pay special attention to bats in particular. Bats are very special mammals because of their diversity, ability to fly long distance and migrate, roosting characteristics and their ability of carrying various pathogens and passing them over to other mammals such as camels, horses, dogs and human beings. With more than 100 species of bats, almost each one of them has been shown to carry pathogens potentially able to cause fatal diseases in humans (Calisher et al., 2006). Bats have possibly been carrying these pathogens for thousands of years, but in recent years there has been increasing human encroachment in their natural habitats and therefore facilitate transfer of pathogens into human population. Fruit eating bats in particular, have highest chances to get into close contact with human population because they share food. Ebola virus RNA was detected in three fruit bats: the hammer-headed fruit bat (Hypsignathus monstrosus), Franquet's epauletted bat (Epomops franqueti), and little collared fruit bat (Myonycteris torquata) and blamed to act as a reservoir to sustain Ebola outbreak in Africa (Leroy et al. 2005). Bats also have been shown to carry other pathogens such as hantavirus, nipah virus, MERS Co-Virus, Marburg virus, Rabies and many more (Calisher et al. 2006, Wynne \& Wang, 2013; Schountz 2015).

Although bats are known to exist in Tanzania, little is known about what species and what pathogens they might be carrying. Furthermore, there are other disease carrying natural hosts such as rodents which are known to be natural hosts of hantavirus, arenaviruses, Lassa virus, lymphocytic choriomeningitis and others and plays a role in sustaining the viruses in the environment and consequently infection in humans (Baumann et al., 2007; http://www.vetmed.ucdavis.edu/ohi/local_resources/pdfs/chapters/32_predict_tanzania.pdf; CDC http://www.cdc.gov/rodents/diseases/direct.html].

\section{Animal handling}

Possibility of infectious disease emerging as result of handling animals and animal product cannot be ruled out. Most of the citizen of Tanzania are either peasants or cattle keepers who therefore have a frequent contact with animals and poultry. Avian influenza for example, throughout history has been shown to be associated with poultry farming, keeping pigs and waterfowls (Kilbourne, 2006; Peiris et al., 2007,). Other diseases such as encephalitis, Rift Valley fever, West Nile fever and many more are known to arise from either direct contact or indirect contract through vector with different kinds of cattle (Gibbs 2005; Peiris et al., 2007).

\section{Bordering with countries having outbreaks of EID}

Bats are known pathogens' hosts of Ebola and Marburg viruses. They have high capacity of migration in large groups with an ability to fly up to $1,000 \mathrm{~km}$ and therefore carry with them deadly pathogens into a totally new geographical location (Epstein et al., 2009). Potential of migrating from Uganda to Tanzania for example cannot be underestimated. Also, primates known to carry Ebola and Marburg viruses in DRC which is bordering Kigoma, Rukwa can easily migrate or infect other primates in Tanzania. Through experience in Ebola outbreak regions in West Africa, we understand how the 
diseases crossed the border to other countries (WHO, 2015). Therefore, the possibilities of diseases spread through infected individuals crossing borders during the incubation period undetected cannot be overemphasized.

\section{Biological warfare and bioterrorism}

Bioterrorism is the use of biological agent on the population with an intent to cause harm. This is different from biological warfare where the target is enemy soldiers. In its wider concept biological terrorism can be defined as the overt or covert use of pathogens, or toxins by individuals, groups, or governments to cause harm for ideological, political, or financial gain (TDSHS, 2011).

While technology allows pathogens to be replicated in the laboratory especially for research purposes, similar technologies fall into the hands of evil menaces and terrorists. It is such availability of disease agents and the ease with which they can be obtained makes emerging pathogens candidates for bioterrorism. However, there is a possibility that bioterrorism could arise from a novel recombinant virus created purely for such purpose with an enhanced virulence. The possibility for genetic engineering and aerosol transmission suggests an enormous potential for bioterrorism. The only significant difference therefore between a naturally occurring epidemic and the one that arises as a result of bioterrorism is the motive (Gibbs, 2005). Extensive of an epidemic is not a prerequisite for causing agent public anxiety; a small localized outbreak arising as a consequence of bioterrorism can cause great havoc, panic and fear that can spread over the whole country.

The US Centres for Disease Control and Prevention (CDC) categorizes emerging viruses causing haemorrhagic fever among others as agents with high-priority (CDC, 2013) that pose a risk to national security because they: (i) can be easily disseminated or transmitted from person to person; (ii) result in high mortality rates and have the potential for major public health impact; (iii) might cause public panic and social disruption; and (iv) require special action for public health preparedness (Table 2).

CDC category A agents are high-priority agents include organisms that pose a risk to national security because they can be easily disseminated or transmitted from person to person, result in high mortality rates and have the potential for major public health impact, might cause public panic and social disruption; and require special action for public health preparedness; such as Influenza, Ebola, Marburg, Small Pox and Lassa Fever. Category B are those pathogens such as Alpha viruses that are moderately easy to disseminate, result in moderate morbidity rates and low mortality rates; and require specific enhancements of diagnostic capacity and enhanced disease surveillance. Category $C$ are third highest priority agents include emerging pathogens that could be engineered for mass dissemination in the future because of their availability, ease of production and dissemination; and potential for high morbidity and mortality rates and major health impact. (http://emergency.cdc.gov/agent/agentlist-category.asp)

\section{Is Tanzania prepared for Emerging Infectious Diseases?}

Infectious disease epidemics pose unique challenges to healthcare as well as national surveillance systems. Since it is often not easy to predict the emergence of infectious diseases, many countries are caught up unprepared in the middle of outbreaks. It is therefore worthwhile to ask ourselves, how prepared are we to respond to infectious disease emergencies and outbreaks. Preparedness for infectious diseases however begins at personal level. It starts by having accurate information about the infectious diseases that are likely to cause epidemics in a specified geographical area. The value of such information is to foster preparedness, including keeping personal protective equipment (PPE) such as respiratory masks and gloves stored at home as part of personal epidemic preparedness plan. In addition, preparedness at personal level should also be accompanied by the 
ability to report in case of unusual syndromes related to emerging diseases. Arguably, it is challenging to implement and monitor PPE at an individual level. However, simple infection control and simple, non-sophisticated PPE that are being applied in daily basis does contribute significantly in limiting the spread of an infectious agent.

On the other hand, as the key to preparedness, national health systems and surveillance as part of the national framework have to be strengthened. Coordinated response from responsible authorities, health workers and the community in general is mandatory to enhance the outcomes. How ready are we at this level? The main components that forms a backbone of any preparedness and response plan that are discussed in this article include a strong disease surveillance and response system and strong healthcare infrastructure. A weak disease surveillance and lack of effective health systems in Sub-Saharan Africa have been described as the major challenges in responding to disease epidemics (Mboera et al., 2014).

\section{Disease surveillance and response}

Disease surveillance is defined as the continual scrutiny of all aspects of occurrence and spread of a disease that are pertinent to effective control. The whole process of surveillance involves the systematic collection, analysis, interpretation, and dissemination of health data (FMT, 2007). Surveillance system are designed to provide early warning of a disease threat by detecting the presence of potentially infectious microorganisms as early as possible. Syndromic surveillance 'collected and careful analysed should serve as an early warning to the public health authorities for a potential outbreak before it spreads further. Data that can be collect and analysed in this approach include number of patients seen at the emergence or outpatient department, symptoms observed, specific geographical area from which come patients seen with symptoms suggestive of emerging disease outbreak. The more surveillance data are collected, the more likely to identify early the emerging of an infectious disease in the community. A monitoring and evaluation study done in Tanzania revealed a weakness in reporting and analysing surveillance data from the facility level (Rumisha et al., 2007).

With a modern technology, surveillance has been digitalized. With an increasing reputation Digital Surveillance focuses on collecting information from the internet on symptoms as well as rumours of potentially spread of an infectious disease (Nelson et.al 2012; Wojcik et.al 2014). Satellite information which monitors movements of people to health care facilities and drug counters as a proxy for early outbreak warning has been tested (Brownstein, 2014). Mobile phone applications have been considered as another alternative that can facilitate mobile phone users to report symptom related to emerging disease (Nsoesie et.al., 2014). Laboratories provides data related to pathogens detected, healthcare workers provide information on cases identified through electronic records; all this information is linked directly to the digital surveillance systems (Brownstein, 2014). Additionally, the use of web pages dedicated for surveillance (such as PRO-MED) as well as social media to assess information that is passed among experts and members of the community on disease occurrences is among effective surveillance means identified and used in digital surveillance (Nsoesie et.al., 2014).

The purpose of surveillance in this context should be to collect information that can serve as early warning for emerging of an infectious outbreak. Location where the disease is emerging, the number of patients exhibiting the symptoms, patterns of disease spread and deaths are early indicators to what kind of viral pathogens is involved. Collection of such information can be expanded by involving members of the community in "participatory surveillance". Understanding of what need to be reported as well as why it is important to report, when to report, where to report, how to report, equips the community to get involved in surveillance. The Tanzania disease surveillance system has adopted the Integrated Disease Surveillance and Response (IDSR) strategy 
which operates under the Ministry responsible for public health. The IDSR strategy forms part of preparedness plan however, mainly focusing on collecting information from health care facilities (Rumisha et al., 2007; WHO, 2012). The system is faced by a number of challenges including timeliness, completeness and data quality (Franco et al., 2005; Rumisha et al., 2007). This results in missing data that could provide timely key information in infectious disease trends in our country.

Rapid response involves processes of deployment of teams, supplies and relevant assistance to respond against a suspected emerging disease outbreak in a minimum time possible. This includes deployment of health staffs to the affected area, investigations and ability to diagnose the specific pathogen responsible for an outbreak tailored with supplying PPE for and medications for disease management. The team deployed should ideally be well trained to respond to such situations. However, shortage of health care worker let alone lack of training to respond to outbreaks is among the major bottlenecks in outbreak response. A recent study in Tanzania has identified key challenges for timely response to include uninformed and unskilled health staff, breaches in national surveillance system leading to communication gaps between local and national levels and lack of resources including human, financial and infrastructure required for a rapid response to disease outbreaks (Froeschl et al., 2016).

\section{Public health systems}

Although the national framework for outbreak response exists and has been communicated, local health authorities are less aware and have not implemented most of its directives (Froeschl et al. 2016). However, requirement for training and infrastructure are enormous and require substantial investment. Infectious disease outbreak will often cause large number of patients requiring diagnostic capacity and hospitalization (Kruk, 2008). The majority will need advanced life support such as mechanical ventilation, isolation and/or highly specialized intensive treatment. Quarantine facilities may be required for diseases that are highly contagious. However, most of our healthcare facilities do not have adequate resources or infrastructure needed to manage all aspects of care during the period that lasts longer than few days in a diseases outbreak situation (CDC 2011; Thompson \& Zwi, 2011).

Tanzania has inadequate laboratory capacity that is capable of handling highly infectious pathogens which normally require beyond level 2 safety laboratory to diagnose the emerging viral agents in an acceptable shorter time frame. Ever mutating viral agents responsible for emerging diseases also require novel diagnostic technology which is unavailable (Howard \& Fletcher 2012). This delay in diagnosis wastes critical time in early response to an outbreak and may cause high casualties in both community and among health staffs. The current efforts by the government to upgrade few laboratories and build capacity to be able to diagnose emerging viral pathogens are cornerstone towards early identification of microbial agents for an effective control measures (CDC 2011; Nangawe, 2012). Moreover, as a country, we do not have a health facility that is prepared to handle patients infected with highly infectious viral agents in isolation. Lack of prepared and well-designed isolation infrastructures for quarantine according to recommendations usually fuels up transmission in early day of outbreak as a result of nosocomial spread of an infectious agent (CDC, 2011). In this case health care workers usually become the first victims (Froeschl et al., 2016). Intersectoral collaboration in addressing zoonoses is still weak in Tanzania (Mbugi et al., 2012; Mboera et al., 2014). The recent efforts to develop a National One Health Strategic plan is a welcome initiative.

\section{Conclusion}

Emerging infectious diseases are increasing threat to human wellbeing and public health in general. New pathogens are identified and those previously existed in limited location cause disease in wide 
geographical area. Changes in disease presentation and increase virulence of previously less virulent pathogens is another major concern in emerging infectious diseases. Driving force and factors to emergence of pathogens and diseases also becomes more prominent. Human demographic changes which causes massive changes in land use and therefore considerably alters ecosystem results into increase human and animal contact. Together with economic activities and increase in animal protein demand puts human population more susceptible to diseases of zoonotic nature. Previous recent outbreaks and epidemics have taught us a lesson that political boundaries are completely ineffective to prevent diseases from crossing borders. Advance and effective travel systems and airline interconnection puts the whole globe into almost the same level of danger from an epidemic that occurs several kilometres away in a different continent.

Despite this danger, most of developing countries are less prepared to face such epidemics. Tanzania, just like other developing countries has inadequate capacity and capability for early detection and response to EIDs. It is important to map what capacity exists within the country to form the basis of very initial and rapid response before reaching for international assistance. As mean of increasing our level of preparedness, we recommend the following to be considered. Increase public awareness on possible emerging diseases and what exactly can be of great concern in what season. The community needs to be informed on reporting systems of early warning signs, how to employ personal protection and simple but important components of preparedness including family PPE. This is the cornerstone towards prevention of spread of pathogens within the community. Community awareness will enable extension of the current working surveillance plan to involve the community participation.

It is important to introduce and strengthen training of the community health workers and healthcare staffs on how to respond to a potential outbreak of viral emerging disease pathogen as a very initial point of contact in the health care system. Staffs needs to be trained on better methods of triage for patients who are suspected to have infectious diseases that has the potential to cause outbreaks or epidemics. Effort needs to be made to borrow digital and electronic surveillance technology that can be adopted in our setting and allow quick reception of early warning signs from all directions including the community and health facilities.

Setting infrastructures in selected health facilities, for instance at the tertiary hospitals dedicated to diagnose and offer extensive treatment and care to the affected individuals including isolation and quarantine of infectious cases. When initial cases are effectively quarantined and managed early during its infectious stage, the spread is reduced significantly. The government can start providing PPE for healthcare workers throughout the country as part of preparedness plan to enable them respond to an outbreak immediately as it occurs. Equally important, there is need to enhance one health approach to increase information sharing, surveillance and interventional approach that can minimize outbreaks and the spread of zoonoses. Last but not least we need to enhance research capacity that focuses on explaining natural hosts in the country, their geographical distribution and pathogens they carry. This can be an initial approach towards proper control.

\section{References}

Baumann, A., Dudek, D. \& Sadkowska-Todys, M. (2007) The role of natural environment in spreading of hantavirus - Model of the correlation between host, pathogen and human infections. Przeqlad Edidemiologiczny 61, 647-655

Briese, T., Paweska, J., McMullan, L., Hutchison, S., Street, C., Palacios, G., Khristova, M., Weyer, J., Swanepoel, R., Egholm, M., Nichol, S. \& Lipkin, W. (2009) Genetic detection and characterization of Lujo virus, a new hemorrhagic fever-associated arenavirus from Southern Africa. PLoS Pathogens 4: 5. 
Brownstein, J. (2014) International Meeting on Emerging Diseases and Surveillance: Water, Climate, and Disease Emergence. Vienna, Austria $31^{\text {st }}$ Oct $-3^{\text {rd }}$ Nov. 2014. USA, Computational Epidemiology Group, Harvard Medical School.

Brownstein, J.S., Freifeld, C.C., and Madoff, L.C. (2009) Digital Disease Detection - Harnessing the Web for Public Health Surveillance. New England Journal of Medicine 360, 2153-2157

Calisher, C.H., Childs, J.E., Field, H.E., Holmes, K.V. \& Schountz, T. (2006) Bats: important reservoir hosts of emerging virus. Clinical Microbiology Review 19, 531-545.

CDC (2011) A CDC Framework for Prevention Infectious Diseases. Sustaining the Essentials and Innovating for Future. Centres for Disease Control and Prevention, Atlanta, Georgia.

CDC (2013) Bioterrorism Agents by Categories. Centres for Disease Control and Prevention. Available from: http//emergency.cdc.gov/agent/agentlist-category.asp [Accessed 01 ${ }^{\text {st }}$ February 2015]

Chipwaza, B., Mugasa, J.P., Selemani, M., Amuri, M., Mosha, F., Ngatunga, S.D. \& Gwakisa, P.S. (2014) Dengue and Chikungunya fever among viral diseases in outpatient febrile children in Kilosa District Hospital, Tanzania. PLoS Neglected Tropical Diseases 8(11): e3335.

Crum, J.A., Morrissey, A.B., Nicholson, L.W., Massung, R.F., Staddard, R.A., Galloway, R.L., Ooi, E.E., Maro, V.P., Saganda, W., Kinabo, G.D., Muiruri, C. \& Bartlett, J.A. (2013) Etiology of severe non-malaria febrile illness in northern Tanzania: a prospective cohort study. PLoS Neglected Tropical Diseases 7(7) e2324.

D’Acremont, V., Kilowoko, M., Kyungu, E., Philipina, S., Sangu, W., Kahama-Maro, J., Lengeler, C., Cherpillod, P., Kaiser, L. \& Genton, B. (2014) Beyond malaria - causes of fever in outpatient Tanzania children. New England Journal of Medicine 370, 809-817.

Nangawe, E. (2012) Situation Analysis of Quality Improvement in Health Care, Tanzania 2012. URC and USAID.

Epstein, J.H., Olival, K.J., Pulliam, J.R.C., Smith, C., Westru, J., Hughes, T., Dobson, A.P., Zubaid, A., Rahman, S.A., Basir, M.M., Field, H.E. \& Daszak, P. (2009) Pteropus vampyrus, a hunted migratory species with a multinational home-range and a need for regional management. Journal of Applied Ecology 46, 991-1002.

FAO (2013) World Livestock 2013 - Changing Disease Landscapes. Food and Agriculture Organization, Rome.

Fidler, D.P. (1996) Globalization, International Law, and Emerging Infectious Diseases. Emerging Infectious Diseases 2, 78-84.

FMT (2007) Global Infectious Disease Surveillance and Detection: Assessing the Challenges - Finding Solution. Forum on Microbial Treats, Washington, DC. The National Academic Press.

Franco, L., Fields, R., Mmbuji, P.K.L., Posner, S., Mboera, L.E.G., Jimmerson, A., Senkoro, K.P., Rumisha, S.F., Shayo, E.H. \& Mwami, J.A. (2003) Situation Analysis of Infectious Disease Surveillance in two Districts in Tanzania, 2002. Working Paper. Bethesda, MD: The Partners for Health Reformsplus Project, Abt Associates Inc. <http://www.phrplus.org/Pubs/WPoo4_fin.pdf.

Froeschl, G., Ntinginya, N.E., Sangare, A., Lawala, P., Mangu, C., Dobler, G., Heinrich, N., Flach, B., Nsojo, A. \& Lennemann, T. (2016) Integrating local, national, and international stakeholders in outbreak preparedness in developing countries: conclusions from a conference in Mbeya, Tanzania. Health Security 14, 29-34.

Gibbs, E.P.J (2005) Emerging zoonotic epidemics in the interconnected global community. The Veterinary Records 157, 673-679.

Greer, A.L. (2014) International Meeting on Emerging Diseases and Surveillance: Water, Climate, and Disease Emergence. Vienna, Austria $31^{\text {st }}$ October $-3^{\text {rd }}$ November 2014. University of Guelph, Canada. 
Howard, C.R. \& Fletcher, N.F. (2012) Emerging Virus Diseases: Can we ever expect the unexpected? Emerging Microbes and Infections. e46.

ICAO (2013) Annual Report of the Council 2012. International Civil Aviation Organization. Available from: www.icao.int/publications/Documents/10001_en.pdf [Accessed: 02 Feb 2015]

Kajeguka, D.C., Kaaya, R.D., Mwakalinga, S., Ndossi, R., Ndaro, A., Chilongola, J.O., Mosha, F.W., Schiøler, K.L, Kavishe, R.A. \& Alifrangis, M. (2016) Prevalence of dengue and chikungunya virus infections in north-eastern Tanzania: a cross sectional study among participants presenting with malaria-like symptoms. BMC Infectious Diseases 16:183

Karimuribo, E.D., Mboera, L.E.G., Mbugi, E., Simba, A., Kivaria, F.M., Mmbuji, P. \& Rweyemamu, M.M. (2011) Are we prepared for emerging and re-emerging diseases? Experience and lessons from epidemics that occurred in Tanzania during the last five decades. Tanzania Journal of Health Research 13, 387-398.

Kilbourne, E.D. (2006) Influenza Pandemics of the $20^{\text {th }}$ Century. Emerging Infectious Disease 12, 9-14.

Kilbourne, E.D. (2016) Influenza Pandemics of the $20^{\text {th }}$ Century. Emerging Infectious Disease 20 (1). doi: 10.3201/eid1201.051254

Kruk, M.E. (2008) Emergency preparedness and public health systems. lessons for developing countries. American Journal of Preventive Medicine 34, 529-234.

Lam, S. (2003) Nipah Virus - A potential Agent of Bioterrorism? Antiviral Research 57, 113-119.

Leroy, E.M., Kumulungui, B., Pourrut, X., Rouquet, P., Hassanin, A., Yaba, P., Delicat, A., Paweska, J.T., Gonzalez, J.P. \& Swanepoel, R. (2005) Fruit bats as reservoirs of Ebola virus. Nature 438, 575576.

Madjid, M., Lillibridge, S., Mirhaji, P. \& Casscells, W. (2003) Influenza as bioweapon. Journal of the Royal Society of Medicine 96, 345-346.

Maron, D.F. (2014) Weaponized Ebola: Is it Really a Bioterror Threat? [Online] Scientific American. Available from: http://www.scientificamerican.com/article/weaponized-ebola-is-it-really-abioterror-threat/ [Accessed: $4^{\text {th }}$ Apr 2015]

Martson, H.D., Folkers, G.K., Morens, M.D. \& Fauci, A.S. (2014) Emerging viral diseases: confronting threats with new technologies. Science Translation Medicine 6:253

Mboera, L.E.G., Mfinanga, S.G., Karimuribo, E.D., Rumisha, S.F. \& Sindato, C. (2014) The changing landscape of public health in sub-Saharan Africa: Control and prevention of communicable diseases needs rethinking. Onderstepoort Journal of Veterinary Research 81(2) Art. \#734, 6 pages. http://dx.doi.org/10.4102/ojvr. v81i2.734

Mboera, L.E.G., Mweya, C.N., Rumisha, S.F., Tungu, P.K., Stanley, G., Makange, M.R., Misinzo, G., De Nardo, P., Vairo, F. \& Oriyo, N.M. (2016) The risk of Dengue virus transmission in Dar es Salaam, Tanzania during an epidemic period of 2014. PLoS Neglected Tropical Diseases 10(1): e004313.

Mbugi, E.V., Kayunze, K.A., Katale, B.Z., Kendall, S., Good, L., Kibiki, G.S., Keyyu, J.D., GodfreyFaussett, P., van Helden, P. \& Matee, M.I. (2012) 'One Health' infectious diseases surveillance in Tanzania: Are we all on board the same flight? Onderstepoort Journal of Veterinary Research 79(2): e2500

MALF (2016) The Tanzania Smallholder Livestock Sector. A review based on the 2012/13 National Panel Survey. Tanzania. Ministry of Agriculture, Livestock and Fisheries, United Republic of Tanzania.

Monath, T.P. (1993) Arthropod-borne viruses. In: S.S. Morse (ed). Emerging viruses. New York: Oxford University Press.

Morens, D.M. \& Fauci, A.S. (2013) Emerging infectious diseases: threats to human health and global stability. PLOS Pathogens 9(7): 1-3. 
Morens, M.D., Folkers, K.G. \& Fauci, S.A. (2004) The challenge of emerging and re-emerging nfectious diseases. Nature. 430, 242-249.

Morens, M.D., Folkers, K.G. \& Fauci, S.A. (2008) Emerging infections: a perpetual challenge. Lancet Infectious Diseases 8, 710-719.

Morse, S.S. (1990) Regulating viral traffic. Issues in Science and Technology 7, 1-4.

Morse, S.S. (1991) Emerging viruses: defining the rules for viral traffic. Perspective in Biology and Medicine 34, 387-409.

Morse, S.S. (1995) Factors in the emerging of infectious diseases. Emerging Infectious Disease 1, 7-15.

Murphy, F.A. (2008) Emerging zoonoses: The challenge for public health and biodefense. Preventive Veterinary Medicine 86, 216-223.

Muzzini, E. (2008) The Urban Transition in Tanzania, Building the Empirical Base for Policy Dialogues. The World Bank, Washington, USA

Neinrich, N., Saathoff, E., Weller, N., Clowes, P., Kroidl, I., Ntinginya, E., Machibya, H., Maboko, L., Loscher, T., Dobler, G. \& Hoelscher, M. (2014) High seroprevalence of Rift Valley fever and evidence for endemic circulation in Mbeya Region, Tanzania, in a cross-sectional study. PLoS Neglected Tropical Diseases 6(3): e2979

Nsoesie, O.E., Kluberg, S.A., Mekaru, S.R., Majumder, M.S., Khan, K. \& Browstein, J.S. (2015) New digital technologies for the surveillance of infectious diseases at mass gathering events. Clinical Microbiology and Infections 21, 134-140.

Peiris, J.S.M., de Jong, M.D. \& Guan, Y. (2007) Avian influenza virus (H5N1): a threat to human health. Clinical Microbiology Reviews 20, 243-267.

Peters, C.J. \& Le Duc, J.W. (1999) An introduction to Ebola: The virus and the Disease. The Journal of Infectious Diseases. 179 (Suppl1), ix-xvi.

ProMED-Mail Updates [Online] Availabele from: www.promedmail.org.

Racaniello, V.R. (2004) Emerging infectious diseases. Journal of Clinical Investigation 113, 798-798.

Rumisha, S.F., Mboera, L.E., Senkoro, K.P., Gueye, D., Mmbuji, P.K. (2007) Monitoring and evaluation of integrated disease surveillance and response in selected districts in Tanzania. Tanzania Health Research Bulletin 9, 1-11.

Scholz, S., Ngoli, B. \& Flessa, S. (2015) Rapid assessment of infrastructure of primary health care facilities - a relevant instrument for health care systems management. BMC Health Services Research 15:183.

Schountz, T. (2015) Immunology of bats and their viruses: challenges and opportunities. Viruses 6: 4880-4901

Sidwell, R.W. \& Smee, D.F. (2003) Viruses of Bunya- and Togaviridae: potential as Bioterrorism agents and means of control. Antiviral Research 57, 101-111.

Suleiman, S.S. (2014) World Airport Summit 2014: Tanzania Airports Expansion Master-plan and Future Development Trends. Munich, September 2014. Dar-es-salaam, Tanzania Airport Authority

Tatem, A.J., Rogers, D.J. \& Hay, S.I. (2006) Global Transport Networks and Infectious Diseases Spread. Advanced Parasitology 62, 293-343.

TDSHS (2011) History of bioterrorism. Texas Department of State Health Services. Available from: http://www.dshs.state .tx.us/preparedness/bt_public_history.shtm [Accessed: 02 ${ }^{\text {nd }}$ Feb 2015]

Thompson, L. \& Zwi, A. (2011) HRH in Public Health Emergencies in developing countries: an overview. [Online] Available from sphcm.med.unsw.edu.au Human Resource for Health Knowledge Hub. [Accessed: 10th Mar 2016]

Trifonov, V., Khiabanian, H. \& Rabadan, R. (2009) Geographic dependence, surveillance, and origins of the 2009 Influenza A (H1N1) virus. New England Journal of Medicine 361, 115-119.

Vairo, F., Nicastri, E., Meschi, S., Schepisi, S.M., Paglia, G.M., Bevilacqua, N., Mangi, S., Sciarrone, R.M., Chiappini, R., Mohamed, J., Racalbuto, V., Di Caro, A., Capobianchi, M.R. \& Ippolito, G. 
(2012) Seroprevalence of dengue infection: a cross-sectional survey in mainland Tanzania and on Pemba Island, Zanzibar. International Journal of infectious Diseases 16: e44-e46.

Weller, N., Clowes, P., Dobler, G., Saathoff, E., Kroidl, I., Ntinginya, E., Maboko, L., Loscher, T., Hoelscher, M. \& Neinrich, N. (2012) Seroprevalence of alphavirus antibodies in a crosssectional study in south-western Tanzania suggests endemic circulation of Chikungunya. PLoS Neglected Tropical Disease 8(7): e1557.

Wenban-Smith, H.B. (2014) Population growth, internal migration and urbanization in Tanzania, 19672012: a census based regional analysis. Working Paper 1: London School of Economic, University of Oxford and UK Aid.

Whitley, R.J. (2003) Smallpox: a potential agent of bioterrorism. Antiviral Research 57, 7-12.

WHO (2012) Influenza International Activities, Fiscal Year 2011 Annual Report. WHO African Region (AFR). pp.54-56

WHO (2014) Ebola Situation Report $-04^{\text {th }}$ February 2015. [Online] WHO. Available from: http://apps.who.int/ebola/en/ebola-situation-report/situation-reports/ebola-situation-report4-february-2015 [Accessed: 05th Feb 2015]

WHO (2014) HIV/AIDS Fact Sheet. [Online] WHO. Available from: http://www.who.int/mediacentre/factsheets/fs360/en/ [Accessed: $05^{\text {th }}$ Feb 2015]

WHO (2015) Ebola Virus Disease, Consolidated Preparedness Checklist. Revision 1. [Online] World Health Organization. Available from: http://apps.who.int/iris/bitstream/10665/137096/1/WHO_EVD_Preparedness_14_eng.pdf?ua=1 \&ua $=1$ [Accessed: $06^{\text {th }}$ Feb 2015]

WHO (2015) Factors the contributed to undetected spread of Ebola virus and impeded rapid containment. One Year into Ebola epidemic. [Online] Available from www.who.int [Accessed: 08 ${ }^{\text {th }}$ Aug 2016]

Wilcox, B.A. \& Colwell, R.R. (2005) Emerging and re-emerging infectious diseases: biocomplexity as an interdisplinary paradigm. EcoHealth 2, 244-257.

Wilson M.E. (1995) Travel and the Emergence of Infectious Diseases. Emerging Infectious Diseases 1, 39-49.

Wojcik, O.P., Brownstein, J.S., Chunara, R. \& Johansson, M.A. (2014) Public health for the people: Participatory infectious disease surveillance in the digital age. Emerging Themes in Epidemiology 11(7)

Wynne, J.W. \& Wang, L.F. (2013) Bats and viruses: friend or foe? PLoS Pathogens 9(10): e1003651. 